\title{
VALIDASI KUESIONER ELEMEN PBL YANG MEMPENGARUHI KEPUTUSAN BELAJAR MAHASISWA FAKULTAS KEDOKTERAN DAN ILMU KESEHATAN
}

\author{
Galuh Suryandari*, Yayi Suryo Prabandari**, Rossi Sanusi** \\ * Fakultas Kedokteran dan Ilmu Kesehatan, Universitas Muhammadiyah Yogyakarta, Yogyakarta, Indonesia \\ ** Fakultas Kedokteran, Universitas Gadjah Mada, Yogyakarta, Indonesia
}

\begin{abstract}
Background: Several elements of PBL have been identified and prepared with a questionnaire to be reused. Variables of PBL elements that influence students' learning decisions are assessed using a questionnaire of PBL elements that affect students' learning decisions. This study is one part of a study reported in a different journal of medical education. The objective of this study was to validate a questionnaire of PBL elements that influence learning decisions of students in FKIK UMY

Methods: A total of 584 students from major A, B, C, and D in FKIK UMY on the introductory tutorial groups with Indonesian as discussion language were invited to fill out a questionnaire. Construct validity was assessed by testing the validity of the items, Crönbach alpha, factor analysis, convergent and discriminate validity.

Results: A total of 582 students of the major A, B, C, and D FKIK UMY on the tutorial groups with Indonesian as the language of instruction participated in the study (response rate 99.6\%). Data showed that the questionnaire on PBL elements that affect student learning decisions have a high construct validity.

Conclusion: The questionnaire of PBL elements that influence students' learning decisions in Indonesian version is valid and can be reused. A deeper, further qualitative research on the other PBL elements can be conducted to improve the questionnaire.
\end{abstract}

Keywords: construct validity, factor analysis, elements of PBL, learning decision, students of FKIK UMY

\section{ABSTRAK}

Latar Belakang: Beberapa elemen PBL telah berhasil diidentifikasi dan dibuat kuesioner untuk dapat digunakan kembali. Variabel elemen PBL yang mempengaruhi keputusan belajar mahasiswa dinilai menggunakan kuesioner elemen PBL yang mempengaruhi keputusan belajar mahasiswa. Penelitian ini merupakan satu bagian dari penelitian yang dilaporkan dalam jurnal pendidikan kedokteran yang lain. Tujuan penelitian ini adalah melakukan validasi kuesioner elemen PBL yang mempengaruhi keputusan belajar pada mahasiswa FKIK UMY

Metode: Sebanyak 584 mahasiswa dari prodi A, B, C, dan D FKIK UMY pada kelompok tutorial dengan bahasa pengantar diskusi Bahasa Indonesia diundang untuk mengisi kuesioner. Validitas konstruk dinilai dengan uji validitas item, Crönbach alpha, analisis faktor, validitas konvergen dan diskriminan.

Hasil: Sebanyak 582 mahasiswa prodi A, B, C, dan D FKIK UMY pada kelompok tutorial dengan bahasa pengantar diskusi Bahasa Indonesia berpartisipasi dalam penelitian ini (response rate 99,6\%). Data menunjukkan bahwa kuesioner elemen PBL yang mempengaruhi keputusan belajar mahasiswa memiliki validitas konstruk yang tinggi.

Kesimpulan: Kuesioner elemen PBL yang mempengaruhi keputusan belajar mahasiswa versi Bahasa Indonesia valid dan dapat dipergunakan kembali. Penelitian kualitatif lanjutan yang mendalam tentang elemen PBL lainnya dapat dilakukan untuk menyempurnakan kuesioner.

Kata kunci: validitas konstruk, analisis faktor, elemen PBL, keputusan belajar, mahasiswa FKIK UMY

korespondensi: galuh_suryandari@yahoo.com 


\section{PENDAHULUAN}

Keterampilan belajar mandiri merupakan keterampilan yang penting dalam pembelajaran PBL yang efektif. ${ }^{1}$ Tiga faktor utama yang memiliki persentase terbesar dalam mempengaruhi mahasiswa dalam proses pembelajaran PBL adalah faktor mahasiswa, faktor dosen dan faktor fasilitas. ${ }^{2}$ Faktor yang tidak kalah pentingnya adalah proses belajar yang meliputi kuliah dan tutorial yang konstruktif, mandiri, kolaboratif dan kontekstual serta praktikum yang kontekstual. ${ }^{2}$ Setelah digunakan hampir semua institusi pendidikan kedokteran di dunia, Fakultas Kedokteran dan Ilmu Kesehatan Universitas Muhammadiyah Yogyakarta (FKIK UMY) termasuk salah satu institusi yang menggunakan sistem pembelajaran $\mathrm{PBL}$.

Beberapa elemen PBL telah berhasil diidentifikasi dan dibuat kuesioner untuk dapat digunakan kembali. ${ }^{3}$ Elemen PBL yang telah terbukti mempengaruhi keputusan belajar mandiri mahasiswa adalah permasalahan yang dihasilkan dari diskusi tutorial, isi materi yang diujikan, perkuliahan, tutor, tujuan pembelajaran, dan daftar pustaka., Variabel elemen PBL yang mempengaruhi keputusan belajar mahasiswa dinilai menggunakan kuesioner elemen PBL yang mempengaruhi keputusan belajar mahasiswa. $^{3}$

Penelitian ini merupakan satu bagian dari penelitian yang dilaporkan dalam jurnal pendidikan kedokteran yang lain. ${ }^{5}$ Peneliti perlu memastikan bahwa instrumen yang digunakan valid dan reliabel, karena hal tersebut sangat berpengaruh pada kesimpulan yang akan diambil berdasarkan data yang diperoleh dari instrumen tersebut.

Tujuan penelitian ini adalah melakukan validasi kuesioner elemen PBL yang mempengaruhi keputusan belajar pada mahasiswa FKIK UMY.

\section{METODE}

Kuesioner elemen PBL yang mempengaruhi keputusan belajar mahasiswa ${ }^{3}$ terdiri dari 20 item pernyataan dalam skala Likert 1 sampai dengan $5(1=$ sangat tidak setuju, 2 = tidak setuju, 3 = netral, $4=$ setuju, 5 = sangat setuju). Kuesioner tersebut terbagi menjadi enam subskala yaitu pengaruh diskusi tutorial (DT)
(4 item), pengaruh isi materi yang diujikan (IU) (6 item), pengaruh tujuan blok (TB) (3 item), pengaruh tutor ( $\mathrm{T})$ (3 item), pengaruh dosen (D) (2 item), pengaruh daftar pustaka (DP) (2 item). Penilaian dari kuesioner ini adalah dengan menjumlahkan nilai item pernyataan disetiap dimensi. Telah dilakukan uji reliabilitas terhadap kuesioner ini pada penelitian sebelumnya, menghasilkan koefisien cronbach's alpha sebesar 0,$61 ; 0,67 ; 0,78 ; 0,82 ; 0,60$; dan $0,51 .{ }^{3}$ Hasil konfirmasi faktor analisis dengan menggunakan program Lisrel VII menyatakan bahwa keenam elemen berkorelasi dengan masing-masing item pertanyaannya. ${ }^{3}$

Kuesioner elemen PBL yang mempengaruhi keputusan belajar mahasiswa dalam Bahasa Inggris diterjemahkan ke dalam Bahasa Indonesia oleh staf pengajar di Sekolah Vokasi Program Studi Bahasa Inggris Universitas Gadjah Mada Yogyakarta, kemudian dianalisis kesesuaian terjemahan dengan konteks isi oleh ahli di bidang psikologi pendidikan. ${ }^{3}$ Kuesioner kemudian diujikan secara berulang kepada lima orang mahasiswa yang berbeda untuk menilai pemahaman dan keterbacaan terhadap itemitem pernyataan kuesioner dan semua item dapat terbaca dan dipahami. Kemudian kuesioner hasil uji keterbacaan tersebut diterjemahkan kembali ke dalam Bahasa Inggris oleh penterjemah yang independen dari penterjemah pertama dan belum pernah melihat kuesioner asli dalam bahasa Inggris, yang juga berprofesi sebagai staf pengajar di Sekolah Vokasi Program Studi Bahasa Inggris Universitas Gadjah Mada Yogyakarta untuk melihat kesesuaian makna antara hasil terjemahan kembali dalam Bahasa Inggris dengan instrumen asli. Penelitian ini telah mendapatkan persetujuan dari Komite Etik Kedokteran dan Kesehatan FK UGM.

Pengambilan sampel dilakukan secara stratified random sampling yang besarnya 30\% dari kelompok populasi $(\mathrm{n}=584)$ yang dibagi menjadi empat program studi, yaitu: program studi A (PSA), program (PSC), dan Program studi D (PSD). Setiap program studi dibagi menjadi tiga angkatan, kemudian di setiap angkatan sampel akan diambil secara acak pada kelompok tutorial. Kriteria inklusi adalah mahasiswa yang menggunakan Bahasa Indonesia sebagai bahasa dalam diskusi tutorial dan mahasiswa 
yang telah menjalani sistem pembelajaran PBL selama dua semester, sedangkan kriteria eksklusi adalah mahasiswa yang tidak hadir, mahasiswa yang menolak menjadi responden dan mahasiswa yang memperbaiki/mengulang proses tutorial. Blok yang digunakan untuk pengambilan data adalah blok 7 , blok 13, dan blok 19. Pengambilan data dilakukan pada saat akhir kegiatan tutorial skenario Bahasa Indonesia pada akhir tahap tutorial di masingmasing blok. Penelitian ini telah dilakukan pada akhir semester gasal tahun ajaran 2014/2015.

Pertama, dilakukan uji validitas konstruk diakukan dengan menggunakan uji korelasi Pearson product moment yang dilakukan dengan cara mengkorelasikan skor masing-masing item dengan skor total. Suatu item dinyatakan valid jika $r$ hitung $>r$ tabel. ${ }^{6}$ Nilai $r$ tabel diperoleh dari nilai degrees of freedom $(\mathrm{df})=\mathrm{n}-2$ $(\mathrm{n}=582)$, sehingga diperoleh nilai $\mathrm{r}$ tabel pada nilai $\mathrm{df}$ (580) dengan tingkat kemaknaan 0.05 adalah 0,088. Kedua, dilakukan uji reliabilitas instrumen dengan menghitung nilai internal consistency (Crönbach alpha). Suatu instrumen dikatakan memiliki nilai reliabilitas yang tinggi jika Crönbach alpha $\geq 0.70 .{ }^{7}$

Ketiga, untuk mendapatkan data yang valid instrumen penelitian perlu dianalisis dengan analisis faktor/ explanatory factor analysis (EFA) dengan tahapan uji kelayakan model, matriks anti-images, nilai communalities, komponen matriks, eigenvalue, dan loading factor. ${ }^{8} \mathrm{KMO}$ digunakan untuk mengukur kesesuaian sampel, sementara bartlett's test of sphericity digunakan untuk melihat antar faktor pada variabel berkorelasi secara bermakna atau tidak. Nilai KMO yang dihasilkan harus di atas 0,5 agar faktor layak digunakan dalam penelitian. ${ }^{8}$

Matriks Anti-Images pada dasarnya digunakan untuk melihat ada tidaknya variabel/faktor yang tidak semestinya disertakan dalam analisis faktor karena mempunyai taraf bermaknasi yang sangat kecil. Apabila ada nilai MSA yang lebih kecil dari 0,5 maka indikator tersebut sebaiknya dibuang (tidak diikutkan dalam uji). ${ }^{8}$ Nilai communalities adalah nilai varians yang dijelaskan oleh faktor yang terbentuk terhadap tiap-tiap variabel penelitian. Komponen matriks merupakan matriks yang menunjukkan berapa besar indikator/aitem mampu mempengaruhi variabel penelitian. Eigenvalue adalah jumlah varians yang dijelaskan oleh setiap faktor, dan hanya eigenvalue di atas 1 yang dimasukkan dalam model. Analisis faktor pada penelitian ini digunakan metode ekstraksi principal component analysis dan rotasinya dengan varimax rotation. Item pertanyaan dari setiap variabel diharapkan memiliki factor loadings $>0,40$. Semakin tinggi angka factor loading semakin baik construct validity dari suatu variabel.

Keempat adalah uji validitas diskriminasi untuk melihat dua atau lebih item dalam sub skala yang berbeda memang berbeda, sehingga ditetapkan hipotesis bahwa korelasi antara setiap item dalam sub skala yang berbeda memiliki hubungan yang lemah $(r<0.6)$. Kelima, dilakukan uji validitas konvergen untuk melihat "sub skala - sub skala yang terdapat dalam instrumen mengukur satu konstruk", sehingga ditetapkan hipotesis bahwa korelasi antara sub skala - sub skala yang terdapat dalam instrumen mengukur satu konstruk memiliki nilai korelasi yang kuat $(r>0.6)$.

\section{HASIL DAN PEMBAHASAN}

Respon rate pada penelitian ini sebesar 99,6\%, yaitu sebanyak 582 orang. Responden penelitian dilihat dari jenis kelaminnya mayoritas adalah perempuan $(70,62 \%)$ dan dilihat dari waktu belajarnya mayoritas responden menyatakan waktu belajar jam 15.3017.30 (30,24\%). Responden menurut pengalaman belajar metakognisi, mayoritas responden tidak pernah $(70,62 \%)$, dilihat dari masa belajar mayoritas semester $5(36,43 \%)$, dan dilihat dari program studinya, mayoritas responden berasal dari program studi A $(37,11 \%)$.

Semua item dalam kuesioner elemen PBL yang mempengaruhi keputusan belajar mahasiswa valid karena memiliki $r$ hitung $>0,088$.

Nilai Crönbach alpha elemen PBL yang mempengaruhi keputusan belajar mahasiswa 20 item adalah 0,8252. Berdasarkan analisis faktor elemen PBL yang mempengaruhi keputusan belajar mahasiswa diperoleh nilai $\mathrm{KMO}$ sebesar 0,808 dan Barlett test of sphericity menunjukkan tingkat kemaknaan $(\mathrm{p}=$ 0.000), sehingga data dapat dianalisis lebih lanjut. Terbukti bahwa ternyata semua item pertanyaan mempunyai nilai MSA (measure of sampling adequacy) di atas 0,5 , sehingga semua item dapat diikutkan dan tidak dibuang. 
Tabel 1. Corrected Item-Total Correlation Pada Tiap Item dalam Kuesioner Elemen PBL yang Mempengaruhi Keputusan Belajar Mahasiswa

\begin{tabular}{|c|c|c|c|c|c|c|c|c|c|c|c|}
\hline DT & $\begin{array}{l}\text { Corrected } \\
\text { item-total } \\
\text { correlation }\end{array}$ & IU & $\begin{array}{l}\text { Correct ed } \\
\text { item-total } \\
\text { correlation }\end{array}$ & $\mathrm{TB}$ & $\begin{array}{l}\text { Corrected } \\
\text { item-total } \\
\text { correlation }\end{array}$ & $\mathrm{T}$ & $\begin{array}{l}\text { Corrected } \\
\text { item-total } \\
\text { correlation }\end{array}$ & $\mathrm{D}$ & $\begin{array}{l}\text { Corrected } \\
\text { item-total } \\
\text { correlation }\end{array}$ & $\mathrm{DP}$ & $\begin{array}{l}\text { Corrected } \\
\text { item-total } \\
\text { correlation }\end{array}$ \\
\hline 1 & .4305 & 5 & .3916 & 11 & .3620 & 16 & .4536 & 14 & .4491 & 19 & .3773 \\
\hline 2 & .4040 & 6 & .3884 & 12 & .4300 & 17 & .4621 & 15 & .3973 & 20 & .3502 \\
\hline 3 & .4318 & 7 & .3970 & 13 & .4655 & 18 & .3172 & & & & \\
\hline \multirow[t]{3}{*}{4} & .4108 & 8 & .4177 & & & & & & & & \\
\hline & & 9 & 3919 & & & & & & & & \\
\hline & & 10 & .2909 & & & & & & & & \\
\hline
\end{tabular}

DT=diskusi tutorial; $\mathrm{IU}=$ isi materi yang diujikan; $\mathrm{TB}=$ tujuan blok; $\mathrm{T}=$ tutor; $\mathrm{D}=\mathrm{dosen}$; $\mathrm{DP}=$ daftar pustaka

Nilai communalities item pertama (item nomor 1) bernilai 0,614 yang berarti bahwa item pertama tersebut dapat menjelaskan $61,4 \%$ dari elemen PBL yang mempengaruhi keputusan belajar; pada indikator ke 20 (item nomor 20) sebesar 83,7\%. Hasil tersebut menunjukkan bahwa indikatorindikator tersebut dapat menjelaskan elemen PBL yang mempengaruhi keputusan belajar.

Indikator yang paling besar mempengaruhi variabel penelitian adalah yang mempunyai nilai komponen matriks yang paling besar. Pada kuesioner elemen PBL yang mempengaruhi keputusan belajar, item nomer 10 memiliki nilai komponen matriks yang paling besar yaitu 0,834. Hasil analisis jumlah komponen dari "initial eigenvalues" yang di atas 1 pada instrumen variabel penelitian PBL disajikan pada tabel 2 .

Loading factor pada variabel kuesioner elemen PBL yang mempengaruhi keputusan belajar menunjukkan bahwa tidak ada perubahan susunan item dalam sub skala sebelum dan sesudah dianalisis.

Nilai korelasi antara sub skala juga memperlihatkan hubungan yang lemah $(r<0,6)$ yang dilihat pada Tabel 4 dan nilai korelasi antara setiap item dalam sub skala yang berbeda memiliki hubungan yang lemah $(r<0.6)$ yang dilihat pada Tabel 5. Dengan demikian, hipotesis validitas konvergen tidak dapat dibuktikan,
Tabel 2. Nilai Communalities Masing-Masing Item Pada Variabel Elemen PBL yang Mempengaruhi Keputusan Belajar Mahasiswa FKIK UMY

\begin{tabular}{c|c|c|}
\hline Variabel & $\begin{array}{c}\text { Indikator/ } \\
\text { Item nomor: }\end{array}$ & $\begin{array}{c}\text { Communa- } \\
\text { lities }\end{array}$ \\
\hline Problem based & Item 1 & 0,614 \\
learning (PBL) & Item 2 & 0,714 \\
& Item 3 & 0,684 \\
& Item 4 & 0,534 \\
& Item 5 & 0,386 \\
Item 6 & 0,496 \\
& Item 7 & 0,440 \\
Item 8 & 0,544 \\
Item 9 & 0,375 \\
Item 10 & 0,381 \\
Item 11 & 0,662 \\
Item 12 & 0,707 \\
Item 13 & 0,653 \\
Item 14 & 0,784 \\
Item 15 & 0,797 \\
Item 16 & 0,694 \\
Item 17 & 0,736 \\
Item 18 & 0,543 \\
Item 19 & 0,829 \\
Item 20 & 0,837 \\
\hline &
\end{tabular}


Tabel 3. Jumlah Faktor Terbentuk Berdasarkan "Initial Eigenvalues" di atas 1 Pada Variabel Elemen PBL yang Mempengaruhi Keputusan Belajar Mahasiswa FKIK UMY

\begin{tabular}{l|l|l|l|l|l|l|}
\hline \multirow{2}{*}{ Component } & \multicolumn{3}{|c|}{ Initial eigenvalue } & \multicolumn{3}{c|}{ Extraction sums of squared loadings } \\
\cline { 2 - 7 } & Total & $\begin{array}{l}\text { \% of } \\
\text { Variance }\end{array}$ & $\begin{array}{c}\text { Cumulative } \\
\text { \% }\end{array}$ & Total & $\begin{array}{l}\text { \% of } \\
\text { Variance }\end{array}$ & $\begin{array}{c}\text { Cumulative } \\
\text { \% }\end{array}$ \\
\hline 1 & 4.780 & 23.900 & 23.900 & 4.780 & 23.900 & 23.900 \\
2 & 2.168 & 10.840 & 34.740 & 2.168 & 10.840 & 34.740 \\
3 & 1.637 & 8.183 & 42.923 & 1.637 & 8.183 & 42.923 \\
4 & 1.486 & 7.431 & 50.354 & 1.486 & 7.431 & 50.354 \\
5 & 1.239 & 6.195 & 56.549 & 1.239 & 6.195 & 56.549 \\
6 & 1.101 & 5.506 & 62.055 & 1.101 & 5.506 & 62.055 \\
7 & .940 & 4.702 & 66.757 & & & \\
8 & .756 & 3.779 & 70.536 & & & \\
9 & .723 & 3.616 & 74.152 & & & \\
10 & .672 & 3.358 & 77.510 & & & \\
11 & .640 & 3.199 & 80.709 & & & \\
12 & .581 & 2.904 & 83.613 & & & \\
13 & .528 & 2.640 & 86.254 & & & \\
14 & .500 & 2.500 & 88.753 & & & \\
15 & .458 & 2.290 & 91.043 & & & \\
16 & .409 & 2.043 & 93.087 & & & \\
17 & .388 & 1.940 & 95.027 & & & \\
18 & .365 & 1.825 & 96.852 & & & \\
19 & .347 & 1.733 & 98.585 & & & \\
20 & .283 & 1.415 & 100.000 & & & \\
\hline
\end{tabular}

Extraction Method: Principal Component Analysis

sedangkan hipotesis validitas diskriminan dapat dibuktikan.

Respon rate pada penelitian ini cukup tinggi, yaitu sebesar 99,6\%. Hal tersebut disebabkan karena pengumpulan data dilakukan oleh tutor dalam ruangan tutorial. Mahasiswa yang terpilih sebagai sampel mengisi kuesioner pada saat akhir proses tutorial. Sampel yang gugur disebabkan kuesioner tidak terisi lengkap yang kemungkinan disebabkan karena mahasiswa telah mengisi kuesioner lain $^{5} \mathrm{di}$ awal pertemuan, sehingga pada akhir pertemuan mahasiswa lupa mengisi kuesioner elemen PBL yang mempengaruhi keputusan belajar.

Dari lima hipotesis alat ukur yang ditetapkan dalam penelitian ini untuk menguji validitas konstruk, keempat hipotesis dapat terpenuhi oleh kuesioner elemen PBL yang mempengaruhi keputusan belajar mahasiswa. Validitas konvergen tidak dapat dibuktikan karena nilai korelasi antara setiap item dalam sub skala yang berbeda memiliki hubungan yang lemah $(r<0.6)$, akan tetapi hal tersebut membuktikan bahwa tidak ada item dalam subskala yang berbeda dapat digabungkan atau dihilangkan. Hasil ini telah sesuai dengan penelitian sebelumnya. ${ }^{3}$

Potensi elemen kunci PBL lainnya yang dapat mempengaruhi keputusan belajar mahasiswa, meliputi: tujuan belajar yang disusun oleh mahasiswa, teaching objectives, dan materi yang disampaikan dalam sesi sumber belajar menjadi menarik untuk diteliti lebih lanjut guna menyempurnakan kuesioner ini. Perlu tahapan penelitian kualitatif yang lebih dalam untuk mengidentifikasinya. ${ }^{9}$

Ada beberapa kelemahan dalam penelitian ini, antara lain peneliti mengalami kesulitan dalam melakukan 
Tabel 4. Korelasi Antar Sub Skala dalam Instrumen Elemen PBL yang Mempengaruhi Keputusan Belajar Mahasiswa FKIK UMY

\begin{tabular}{|c|c|c|c|c|c|c|}
\hline \multicolumn{7}{|c|}{ Inter-item correlation matrix } \\
\hline & DT & IU & TB & $\mathrm{T}$ & $\mathrm{D}$ & DP \\
\hline DT & 1.000 & & & & & \\
\hline IU & .267 & 1.000 & & & & \\
\hline TB & .155 & .294 & 1.000 & & & \\
\hline $\mathrm{T}$ & .343 & .282 & .260 & 1.000 & & \\
\hline $\mathrm{D}$ & .298 & .313 & .298 & .298 & 1.000 & \\
\hline DP & .126 & .322 & .275 & .099 & .133 & 1.000 \\
\hline
\end{tabular}

DT=diskusi tutorial; IU=isi materi yang diujikan; TB=tujuan blok; T=tutor; $\mathrm{D}=$ dosen; $\mathrm{DP}=$ daftar pustaka

Tabel 5. Korelasi Antar Item Dalam Instrumen Elemen PBL yang Mempengaruhi Keputusan Belajar Mahasiswa FKIK UMY

\begin{tabular}{|c|c|c|c|c|c|c|c|c|c|c|c|c|c|c|c|c|c|c|c|c|}
\hline \multicolumn{21}{|c|}{ Matriks korelasi antar item } \\
\hline & 1 & 2 & 3 & 4 & 5 & 6 & 7 & 8 & 9 & 10 & 11 & 12 & 13 & 14 & 15 & 16 & 17 & 18 & 19 & 20 \\
\hline 1 & 1.000 & $.568^{* *}$ & $.513^{* *}$ & $.412^{* *}$ & $.179^{* *}$ & $.171^{* *}$ & $.174^{* *}$ & $.161^{* *}$ & $.110^{* *}$ & $.141^{* *}$ & .061 & $.103^{*}$ & $.144^{* *}$ & $.190^{* *}$ & $.227^{* *}$ & $.568^{* *}$ & $.513^{* *}$ & $.412^{* *}$ & $.179^{* *}$ & $.171^{* *}$ \\
\hline 2 & & 1.000 & $.599^{* *}$ & $.442^{*+}$ & .077 & $.111^{* *}$ & $.172^{*+}$ & $.086^{*}$ & .046 & $.094^{*}$ & .063 & $.132^{* *}$ & $.131^{* *}$ & $.177^{* *}$ & $.217^{* *}$ & $.599^{* *}$ & $.442^{*+}$ & .077 & $.111^{* *}$ & $.172^{*+}$ \\
\hline 3 & & & 1.000 & $.473^{* *}$ & $.105^{\circ}$ & $.136^{* *}$ & $.160^{* *}$ & $.114^{* *}$ & .070 & $.135^{* *}$ & .021 & $.149^{* *}$ & $.144^{* *}$ & $.202 *$ & $.269^{* *}$ & $.473^{* *}$ & $.105^{*}$ & $.136^{*}$ & $.160^{* *}$ & $.114^{* *}$ \\
\hline 4 & & & & 1.000 & $.194^{* *}$ & $.157^{* *}$ & $.227^{*+}$ & $.156^{* *}$ & $.103^{*}$ & $.233^{*+}$ & .052 & $.119^{* *}$ & $.107^{* *}$ & $.173^{* *}$ & $.208^{* *}$ & $.194^{* *}$ & $.157^{*+}$ & $.227^{*}$ & $.156^{* *}$ & $.103^{+}$ \\
\hline 5 & & & & & 1.000 & $.345^{* *}$ & $.306^{* *}$ & $.277^{* *}$ & $.156^{*}$ & $.239^{* *}$ & $.200^{* *}$ & $212 *$ & $.208^{* *}$ & $.229^{* *}$ & $.203^{* *}$ & $.345^{*}$ & $.306^{* *}$ & $277^{* *}$ & $.156^{* *}$ & $.239^{* *}$ \\
\hline 6 & & & & & & 1.000 & $.382^{*+}$ & $.336^{*+}$ & $.239^{* *}$ & $.301^{*+}$ & $.128^{* *}$ & $.130^{* *}$ & $.210^{* *}$ & $.198^{* *}$ & $.180^{*+}$ & $.382^{* *}$ & $.336^{*+}$ & $.239^{* *}$ & $.301^{* *}$ & $.128^{*+}$ \\
\hline 7 & & & & & & & 1.000 & $.356^{* *}$ & $.177^{* *}$ & $.233^{* *}$ & $.168^{* *}$ & $.119^{* *}$ & $.200^{\circ *}$ & $.164^{* *}$ & $.194^{* *}$ & $.356^{*}$ & $.177^{* *}$ & $.233^{* *}$ & $.168^{* *}$ & $.119^{* *}$ \\
\hline 8 & & & & & & & & 1.000 & $.411^{* *}$ & $.344^{* *}$ & $.176^{* *}$ & $.173^{* *}$ & $.126^{* *}$ & $.195^{* *}$ & $.176^{* *}$ & $.411^{* *}$ & $.344^{*+}$ & $.176^{*}$ & $.173^{* *}$ & $.126^{* *}$ \\
\hline 9 & & & & & & & & & 1.000 & $.287^{* *}$ & $.093^{\circ}$ & $.109^{* *}$ & $.112^{* *}$ & $.176^{*}$ & $.088^{*}$ & $.287^{*}$ & $.093^{*}$ & $109^{* *}$ & $.112^{* *}$ & $176^{* *}$ \\
\hline 10 & & & & & & & & & & 1.000 & $.157^{* *}$ & $.147^{* *}$ & $.200^{\circ *}$ & $208^{* *}$ & $.158^{* *}$ & $.157^{* *}$ & $.147^{* *}$ & $.200^{* *}$ & $.208^{* *}$ & $.158^{* *}$ \\
\hline 11 & & & & & & & & & & & 1.000 & $.536^{*}$ & $.464^{* *}$ & $221^{* *}$ & $.137^{* *}$ & $.536^{*}$ & $.464^{* *}$ & $.221^{* *}$ & $.137^{* *}$ & $.536^{* *}$ \\
\hline 12 & & & & & & & & & & & & 1.000 & $.554^{* *}$ & $.275^{* *}$ & $.181^{* *}$ & $.554^{* *}$ & $.275^{* *}$ & $.181^{* *}$ & $.554^{* *}$ & $.275^{* *}$ \\
\hline 13 & & & & & & & & & & & & & 1.000 & $.279^{* *}$ & $.156^{* *}$ & $.279^{* *}$ & $.156^{*+}$ & $.279^{* *}$ & $.156^{* *}$ & $.279^{*+}$ \\
\hline 14 & & & & & & & & & & & & & & 1.000 & $.571^{* *}$ & $.216^{*}$ & $.229^{* *}$ & $.184^{* *}$ & $.146^{*}$ & $.134^{* *}$ \\
\hline 15 & & & & & & & & & & & & & & & 1.000 & $.239^{* *}$ & $.233^{*+}$ & $.173^{* *}$ & $.092^{*}$ & .071 \\
\hline 16 & & & & & & & & & & & & & & & & 1.000 & $.631^{* *}$ & $.370^{* *}$ & $.097^{*}$ & .075 \\
\hline 17 & & & & & & & & & & & & & & & & & 1.000 & $.419^{* *}$ & $.112^{* *}$ & $.088^{*}$ \\
\hline 18 & & & & & & & & & & & & & & & & & & 1.000 & .019 & .042 \\
\hline 19 & & & & & & & & & & & & & & & & & & & 1.000 &. .708 $^{\text {t*t }}$ \\
\hline 20 & & & & & & & & & & & & & & & & & & & & 1.000 \\
\hline
\end{tabular}

supervisi dikarenakan pengaturan jadwal tutorial yang bersamaan pada program studi yang berbeda. Kemungkinan adanya kelelahan dan rasa bosan pada subjek penelitian dikarenakan penelitian ini merupakan bagian dari penelitian yang dilaporkan dalam jurnal pendidikan kedokteran yang lain yang menggunakan instrumen dengan total item sebanyak 113 yang harus diisi pada satu waktu pengumpulan, karena sulit untuk melakukan pengumpulan kembali subjek penelitian pada tutorial blok berikutnya disebabkan sistem daftar acak mahasiswa. ${ }^{5}$

\section{KESIMPULAN}

Kuesioner elemen PBL yang mempengaruhi keputusan belajar versi Bahasa Indonesia merupakan instrumen yang valid sehingga dapat digunakan kembali, akan tetapi ada potensi untuk dapat menyempurnakannya kembali dengan penelitian kualitatif yang lebih mendalam dan terencana dengan lebih baik.

\section{UCAPAN TERIMAKASIH}

GS mengucapkan terima kasih kepada dr. Farindira Vesti, M.Sc. yang telah membantu dalam proses 
pengumpulan dan input data. Kepada ibu Erlin Estiana Yuanti, S.S., M.A yang telah menerjemahkan kuesioner elemen PBL yang mempengaruhi keputusan belajar mahasiswa dalam Bahasa Indonesia dan ibu Dewi Handayani, S.S., M.A. yang telah menerjemahkan kembali kuesioner tersebut dalam Bahasa Inggris.

\section{DAFTAR PUSTAKA}

1. English MC, Kitsantas A. Supporting Student SelfRegulated Learning in Problem- and Project-Based Learning. Interdisciplinary Journal of Problem-based Learning. 2013;7(2).

2. Secondira VMR, Retno GR, Suhoyo Y. Faktor-faktor yang mempengaruhi mahasiswa Fakultas Kedokteran Universitas Gadjah Mada untuk melaksanakan pembelajaran yang konstruktif, mandiri, kolaboratif dan kontekstual dalam problem-based learning. Jurnal Pendidikan Kedokteran dan Profesi Kesehatan Indonesia. 2009(4):32-44.

3. Dolmans DHJM, Schmidt HG. What drives the student in problem-based learning? Medical Education. 1994;28:372-80.
4. Dolmans DHJM, Schmidt HG, Gijselaers HG. The relationship between student-generated learning issues and self-study in problem-based learning. Instructional Science (in press); 1994.

5. Suryandari G, Prabandari YS, Sanusi R. Hubungan antara kesadaran metakognisi dengan pengaruh elemen PBL terhadap keputusan belajar dan keterampilan belajar mandiri mahasiswa Fakultas Kedokteran dan Ilmu Kesehatan Universitas Muhammadiyah Yogyakarta. Yogyakarta: [M.Med.Ed tesis] Universitas Gadjah Mada; 2015.

6. Cohen L, Manion L, Morrison K. Research methods in education. New York: Routledge; 2011.

7. Fraenkel JR, Wallen NE, Hyun HH. How to design and evaluate research in education. New York: McGraw Hill; 2012.

8. Widarjono A. Analisis Statistika Multivariate Terapan. Yogyakarta: UPP STIM YKPN; 2010.

9. Blumberg P, Michael JA. Development of selfdirected learning behaviors in partially teacherdirected problem-based curriculum. Teaching and Learning in medicine. 1992; 2: 149-54. 